\title{
SCIENTIFIC REP RTS OPEN Author Correction: Region and species dependent mechanical properties of adolescent and young adult brain tissue
}

\section{David B. MacManus ${ }^{1}$, Baptiste Pierrat ${ }^{1,2,3}$, Jeremiah G. Murphy ${ }^{4}$ \& Michael D. Gilchrist $\mathbb{D}^{1}$}

Correction to: Scientific Reports https://doi.org/10.1038/s41598-017-13727-z, published online 23 October 2017

In the original version of the Supplementary Information file published with this Article, there was a typographical error.

" $\mu$ is the shear modulus $(\mathrm{kPa})$ of the neo-Hookean based viscoelastic model"

now reads:

" $\mu$ is the shear modulus $(\mathrm{Pa})$ of the neo-Hookean based viscoelastic model".

Additionally, in the original Supplementary information file, the R2 standard deviation values in the table for ' 6 week old mouse' were omitted, the table for ' 22 week old pig' contained errors in the rows containing the mechanical data for the cerebellum $(\mathrm{Cbl})$ as well as the mean and standard deviation for the second time constant (t2) for the medulla (Md).

These errors were exclusive to the Supplementary Information and did not affect the main article. These errors have been corrected in the Supplementary Information that now accompanies the Article.

(1) Open Access This article is licensed under a Creative Commons Attribution 4.0 International License, which permits use, sharing, adaptation, distribution and reproduction in any medium or format, as long as you give appropriate credit to the original author(s) and the source, provide a link to the Creative Commons license, and indicate if changes were made. The images or other third party material in this article are included in the article's Creative Commons license, unless indicated otherwise in a credit line to the material. If material is not included in the article's Creative Commons license and your intended use is not permitted by statutory regulation or exceeds the permitted use, you will need to obtain permission directly from the copyright holder. To view a copy of this license, visit http://creativecommons.org/licenses/by/4.0/.

(C) The Author(s) 2018 